Hazard/Risk Assessment

$17-00214$

Hazard/Risk Assessment

J. Yang et al.

Sensitive community responses of microbiota to copper

\title{
SENSITIVE COMMUNITY RESPONSES OF MICROBIOTA TO COPPER IN
}

\section{SEDIMENT TOXICITY TEST ${ }^{1}$}

Jianghua Yang, ${ }^{\text {a }}$ Yuwei Xie, ${ }^{a}$ Katherine Jeppe,${ }^{b}$ Sara Long,,${ }^{\text {Vincent Pettigrove, }}{ }^{\text {b }}$ and XIAOWEI ZHANG 0000-0001-8974-9963 0000-0001-8974-9963 ${ }^{\mathrm{a}, *}$

${ }^{a}$ State Key Laboratory of Pollution Control \& Resource Reuse, School of the

Environment, Nanjing University, Nanjing, China

${ }^{\mathrm{b}}$ Centre for Aquatic Pollution Identification and Management, School of BioSciences,

The University of Melbourne, Parkville, Australia

(Submitted 22 March 2017; Returned for Revision 18 April 2017; Accepted 6 September

\footnotetext{
1 This is the author manuscript accepted for publication and has undergone full peer review but has not been through the copyediting, typesetting, pagination and proofreading process, which may lead to differences between this version and the Version of Record. Please cite this article as doi:10.1002/etc.3980
} 


\begin{abstract}
Sediment contamination is widespread and can be toxic to aquatic ecosystems and impair human health. Despite their significant ecological function, meio- and microbiota in aquatic ecosystems have been poorly studied in conventional sediment ecotoxicity tests because of the difficulty in sample collecting and identification. In the present study, a novel DNA metabarcoding method was used to assess the effects of spiked copper $(\mathrm{Cu})$ on benthic eukaryotic and prokaryotic communities in laboratory sediment toxicity tests with macroinvertebrates, the chironomid Chironomus tepperi and the amphipod Austrochiltonia subtenuis. In addition to the obvious toxic effects to experimental animals, microbiota (bacteria, protists, algae, and fungi) were significantly altered by spiked $\mathrm{Cu}$ in the sediments. The phylogenetic diversity of eukaryotic communities was decreased after spiked-Cu exposure. Even a low-spiked $\mathrm{Cu}$ treatment $(125 \mathrm{mg} / \mathrm{kg})$ altered structures of eukaryotic and prokaryotic communities in the amphipod experiment. The present study demonstrates that measuring microbiota communities will expand our understanding of the influences of contaminants on aquatic ecosystems. Particularly, the alterations of phylogenetic biodiversity of eukaryotic communities and the structure of sedimentary communities are sensitive indicators for sediment contamination, which can be incorporated in the monitoring and assessment of sediment quality.
\end{abstract}

Keywords: Sediment toxicity test, Copper, Eukaryotic community, Prokaryotic community 
* Address correspondence to zhangxw@nju.edu.cn

Published online 11 September 2017 in Wiley Online Library

(www.wileyonlinelibrary.com). DOI: 10.1002/etc.3980

\section{INTRODUCTION}

Sediment contamination is widespread and can be toxic to aquatic ecosystems and impair human health [1]. Assessing the impacts of toxic sediment contaminants on aquatic biota is important for ecological health assessment. Laboratory-based bioassays are well-accepted approaches to assess the effects of sediment contaminants by evaluating the changes in toxicological response of specific organisms [2]. Most sediment toxicity tests focus on the effects of sediment contaminants on laboratory-cultured macrofauna, such as phytoplankton [3], macroinvertebrates [4], and macrophytes [5]. These tests have been criticized for lacking environmental relevance [6]. A recent mesocosm study showed that the responses of some taxa of meio- and microbiota, including Chlorophyta, Nematoda, Bacillariophyta, and fungi, were more sensitive to copper $(\mathrm{Cu})$ than macroinvertebrates [7]. Furthermore, prokaryotes may also be affected by contaminants and may often be more sensitive than eukaryotic communities [8]. However, the current understanding of sediment microbiota responses to sediment contamination is limited, and how to incorporate these responses into current ecotoxicological assessments has not been addressed. 
Sediments contain complex and diverse microbiota, which are an essential component of aquatic ecosystems. They play a critical role in many important biogeochemical processes, including nutrient cycling and degradation of some contaminants $[9,10]$, and are essential for survival of animals and plants [11]. Recent studies on soil microbial ecology have shown that the diversity and composition of microbial communities are the key factors controlling biochemical processes and prevent the invasion of bacterial pathogens $[12,13]$. For example, a reduction in microbial diversity by dilution reduced nitrogen cycling in soil [14]. Sediments have a variety of physical-chemical properties as soil; however, knowledge concerning alteration of the diversity and composition of sediment microbial communities in response to contaminants is limited.

The increased resolution of next-generation sequencing technology combined with DNA barcoding (DNA metabarcoding) has greatly improved our ability to identify diverse taxonomic groups of the microbiota $[15,16]$. Metabarcoding of DNA has the potential to not only assess phylogenetic biodiversity more reliably and rapidly than ever before but also provide a cost-effective tool to evaluate the community structures that are relevant to the function of microbiota [17].

The present study investigated the responses (phylogenetic diversity, community structure, and sensitive taxa) of the meio- and microbiota in standard sediment toxicity tests of spiked $\mathrm{Cu}$. Two benthic macroinvertebrate species, Chironomus tepperi (Diptera: Chironomidae) and Austrochiltonia subtenuis (Amphipoda: Chiltoniidae), were employed 
in chronic sediment toxicity testing (18 and $21 \mathrm{~d}$ for chironomid and amphipod experiments, respectively) of spiked-Cu sediment in the laboratory. The diversity and structure of eukaryotic and prokaryotic communities were characterized by DNA metabarcoding in addition to evaluation of the lethal and sublethal toxicity at the end of exposure.

\section{METHODS}

\section{Sediment spiking}

Sediment was collected from an uncontaminated wetland (Glynns wetland, Warrandyte, $30 \mathrm{~km}$ east of Melbourne, Australia). Sediment was sieved to $63 \mu \mathrm{m}$ and allowed to settle for $24 \mathrm{~h}$. Sediment was spiked using methods from Simpson et al. [18], with adjustments to "dilution pH 7" spiking, whereby a high-spike sediment stock (6000 $\mathrm{mg} / \mathrm{kg} \mathrm{Cu}$ ) was diluted to improve binding and equilibration of metal to sediment [19]. After equilibration, the stock sediment was diluted to 5 exposure concentrations of $\mathrm{Cu}$ $(62.5,125,250,500$, and $750 \mathrm{mg} / \mathrm{kg})$ by the unspiked sediments. The spiked sediment was taken at the start and end of the experiment for chemical analysis of total $\mathrm{Cu}$ by inductively coupled plasma atomic emission spectroscopy [20]. The measured concentrations did not differ from the nominal spiked concentrations by more than $10 \%$.

\section{Sediment toxicity bioassays}

Sediment toxicity experiments were performed following the procedures described in Gagliardi et al. [21] and $\mathrm{Vu}$ et al. [22]. Test organisms were originally 
collected in the field and cultured in the laboratory for at least 6 mo with an artificial freshwater medium (chironomids, $0.07 \mathrm{mM} \mathrm{CaCl}_{2}, 0.1 \mathrm{mM} \mathrm{NaCl}, 0.08 \mathrm{mM} \mathrm{MgSO}_{4}, 0.12$ $\mathrm{mM} \mathrm{NaHCO} 3,0.01 \mathrm{mM} \mathrm{KH}_{2} \mathrm{PO}_{4}$, and $0.01 \mu \mathrm{M} \mathrm{FeCl}_{3}$; amphipods, $4.71 \mathrm{mM} \mathrm{NaCl}, 2.3$ $\mathrm{mM} \mathrm{NaHCO} 3,1.73 \mathrm{mM} \mathrm{MgCl} 2$ hydrous, $0.61 \mathrm{mM} \mathrm{CaCl}_{2}$ hydrous, $0.48 \mathrm{mM} \mathrm{NaBr}, 0.32$ $\mathrm{mM} \mathrm{MgSO}_{4}$, and $0.09 \mathrm{mM} \mathrm{KCl}$ ) [22]. Experimental animals were cultured in a glass tank with cotton gauze at a constant room temperature of $21^{\circ} \mathrm{C}$. Toxicity testing was performed in a $600-\mathrm{mL}$ beaker. Each beaker contained $140 \mathrm{~g}$ of spiked-Cu sediment (wet) and $400 \mathrm{~mL}$ of artificial freshwater. Each treatment had 4 replicates. Experiments were maintained at $21^{\circ} \mathrm{C}$ in an illumination incubator with $16 \mathrm{~h}$ light and $8 \mathrm{~h}$ dark. Aeration was provided to maintain saturated dissolved oxygen in the system. The test duration was $18 \mathrm{~d}$ for C. tepperi and $21 \mathrm{~d}$ for A. subtenuis.

In the chironomid experiment, 10 larvae $(5 \mathrm{~d}$ old) were randomly collected and added into each vessel. The overlying water was changed 3 times per week. One week after the experiment started, emergence was checked and adults were collected every day. After $5 \mathrm{~d}$ of exposure, half of the test animals were collected and rinsed in clean medium. The animals were placed in sterile 1.5 -mL Eppendorf tubes and dried at $60{ }^{\circ} \mathrm{C}$ for $72 \mathrm{~h}$. Dry weight was measured to determine chironomid growth.

In the amphipod experiment, 10 amphipods (7-14 d old) were randomly collected and added into each vessel. Overlying water was changed weekly. Animals were fed during the experiment with a food suspension $(1 \mathrm{~mL} / \mathrm{d})$ that contained $10 \mathrm{~g}$ of fish feed 
(TetraMin) and $50 \mathrm{~mL}$ artificial medium. These amphipods were also fed a small amount

(2 drops) of rotten leaves (green hazel, Pomaderris aspera) per day [22].

DNA isolation

At the end of the experiments, the overlying water was decanted and the sediment dispersed to carefully collect unemerged larvae. Sediments were not sieved, to minimize the impact on the microbial community. All sediments were freeze-dried in 50-mL tubes and homogenized before DNA isolation. Approximately $0.3 \mathrm{~g}$ of homogenized sediment was used to extract the environmental DNA with the MoBio Power Soil DNA Kit (MoBio Laboratories) following the manual. The purity of the DNA was checked in a Take3 microplate in the Synergy H4 Hybrid Multi-Mode Microplate reader (BioTek) and quantified by use of Qubit dsDNA HS assay kits (Invitrogen). Polymerase chain reaction amplification and next generation sequencing

Bacterial 16S ribosomal RNA genes and eukaryotic $18 \mathrm{~S}$ ribosomal RNA genes were amplified using V3 primers (modified primers 341F and 518R) [23] and V9 primers (1380F and 1510R) [24], respectively. Triplicate polymerase chain reactions (PCRs) were performed for each sample to minimize potential PCR bias. Ion sequencing adapters were linked to the PCR fragments with IonXpress ${ }^{\mathrm{TM}}$ Plus Library Kits (Life Technologies). The PCR amplicon libraries were adjusted to a final concentration of $100 \mathrm{pM}$, attached to ion sphere particles using the ion proton template OT2 200 kit (Life Technologies), and 
sequenced in the ion torrent proton according to the manufacturer's protocols (Ion PI Sequencing 200 Kit Ver 2; MAN0007961).

\section{Bioinformatics}

The low-quality sequences (quality $<20$, scanning window $=50$ ) and sequencing adapter sequences were filtered [25]. Denoising, chimera removal, and operational taxonomic units were selected with a sequence similarity cutoff of $97 \%$ following the UPARSE pipeline [26]. For each operational taxonomic unit, a representative sequence was chosen and taxonomy was assigned using the Ribosomal Database Project classifier [27] against the Greengenes [28] and SILVA databases [29] for prokaryotic and eukaryotic communities, respectively. The operational taxonomic units, which were assigned to the same taxon were combined together to estimate the abundance of the taxon. The relative abundance of each taxon was the proportion of reads in each next-generation sequencing sample.

\section{Statistical analysis}

All statistical analyses were conducted in R (Ver 3.3.0). The response of dry weight (chironomid), emergence rate (chironomid), and survival rate (amphipod) to spiked-Cu exposure was modeled with a 3-parameter log-logistic model and the 50\% effect concentration (EC50) calculated [30]. The relationship between spiked $\mathrm{Cu}$ and taxon abundance was analyzed by Pearson correlation, and highly correlated taxa were determined by rho $>0.5$ and $p<0.05$. Beta diversity was estimated by computing 
weighted UniFrac distances between samples [31]. All samples were rarefied at the lowest sequencing depth to reduce biases resulting from differences in sequencing depth (8134 and 14000 for eukaryotic and prokaryotic communities, respectively). Principal component analysis was employed to cluster microbial communities of each sample according to the level of spiked $\mathrm{Cu}$. The diversity of microcommunities was estimated by the Chao1 method, which is the most popular bioindex for microbial community assessment [32]. Highly tolerant taxa were those with a relative abundance positively correlated with spiked $\mathrm{Cu}$ in Pearson correlation analysis (rho $>0.5$ and $p<0.05$ ). The emergence time of chironomids is the time from the second-instar larvae being added at the start of the experiment to the emergence of adults.

The threshold of spiked $\mathrm{Cu}$ to microbiota was determined by the lower quartiles of the EC10 values of all sensitive taxa. Firstly, the abundance of each sensitive taxon was normalized by the formula $\frac{\boldsymbol{x}-\min (x)}{\max (\boldsymbol{x})-\min (x)}$, where $x$ is the abundance of each sensitive taxon. Secondly, the relationship between normalized abundance and spiked $\mathrm{Cu}$ was fitted by the 3-parameter log-logistic model, and then the EC10 was calculated. Finally, the threshold of spiked $\mathrm{Cu}$ was calculated by the lower quartiles.

\section{RESULTS}

Effect of spiked-Cu sediment on $\mathrm{C}$. tepperi and A. subtenuis

Both $C$. tepperi and A. subtenuis were toxicologically responsive to spiked-Cu sediment. Spiked $\mathrm{Cu}$ significantly inhibited the growth and emergence rate of $C$. tepperi 
in a concentration-dependent manner; however, its survival rate was not significantly altered (Figure 1A). Spiked $\mathrm{Cu}$ also delayed their emergence time (Figure 1B). The EC50 of dry weight and emergence rate were $192 \pm 30.6$ and $459 \pm 12 \mathrm{mg} / \mathrm{kg}$, respectively. The survival rate of $A$. subtenuis also decreased significantly in a concentration-dependent manner, with a median lethal concentration of $484.3 \pm 72.1 \mathrm{mg} / \mathrm{kg}$ (Figure 1C).

\section{Composition of eukaryotic and prokaryotic communities in sediments}

A total of 853368 prokaryotic sequences were obtained by next-generation sequencing. After being filtered, 680841 high-quality sequences were retained; and these sequences were clustered into 932 prokaryotic taxa. The sequencing depth of each sample varied from 14063 to 29321 . The prokaryotic communities in sediment were dominated by Proteobacteria (12.2-37.8\%, mean 23.0\%), Firmicutes (5.5-42.3\%, mean 19.7\%), Bacteroidetes (2.6-20.1\%, mean 10.8\%), Chloroflexi (4.7-15.8\%, mean 10.0\%), Cyanobacteria (1.4-16.8\%, mean 8.1\%), Actinobacteria (1.9-19.3\%, mean 7.6\%), Planctomycetes (3.1-10.3\%, mean 5.7\%), and Verrucomicrobia (1.5-6.7\%, mean 4.2\%). The sum of these 7 assemblages accounted for approximately $89.1 \%$ of overall prokaryotic communities (Figure 2A).

For eukaryotic communities, 738889 in 1098427 raw sequences were retained and 980 eukaryotic taxa were discovered from these high-quality sequences. Algal communities were dominated by Chlorophyta (0.04-34.9\%, mean 20.0\%), Ochrophyta (0.23-54.6\%, mean 10.5\%), and Dinophyta (0.06-53.2\%, mean 23.8\%). Ciliophora 
(0.5-28.5\%, mean 13.8\%), Cercozoa (0.1-20.0\%, mean 13.8\%), and Discoba

$(0.01-18.1 \%$, mean $0.04 \%)$ dominated the protozoan assemblage. Fungi represented

$17.5 \%(0.6-35.4 \%)$ reads of the overall eukaryotic communities (Figure 2B).

\section{Variations in community structure}

The structures of prokaryotic and eukaryotic communities displayed a significant separation among spiked-Cu sediments in both amphipod and chironomid experiments (Figure 3A,B). In amphipod experiments, the weighted UniFrac distances of both prokaryotic and eukaryotic communities were altered significantly if the concentration of spiked $\mathrm{Cu}$ was $>125 \mathrm{mg} / \mathrm{kg}$. In chironomid experiments, the weighted UniFrac distances of prokaryotic communities were changed significantly when spiked $\mathrm{Cu}$ was $>250 \mathrm{mg} / \mathrm{kg}$, and the weighted UniFrac distance of eukaryotic communities was changed significantly when spiked $\mathrm{Cu}$ was $>500 \mathrm{mg} / \mathrm{kg}$ (Table 1 ).

In addition, alpha-diversity measures (Chao1 index) were significantly different among the spiked-Cu treatments (Figure 3C,D). In low-Cu treatments (125 and 250 $\mathrm{mg} / \mathrm{kg})$, the diversities of prokaryotic communities were increased $(p<0.05)$ in amphipod experiments. In high-Cu treatments (500 and $750 \mathrm{mg} / \mathrm{kg}$ ), the diversities of eukaryotic communities decreased $(p<0.05)$ in both amphipod and chironomid experiments. Response of eukaryotic and prokaryotic taxa to $\mathrm{Cu}$-spiked sediments 
Twenty-nine out of 980 eukaryotic taxa were negatively correlated with the concentrations of spiked $\mathrm{Cu}$ (Pearson correlation, rho $<-0.5$ and $p<0.05$ ) in both amphipod and chironomid experiments (Figure 4). Most of the sensitive taxa belonged to Archaeplastida, Fungi, Protozoa, and Stramenopiles. Only 5 eukaryotic taxa across 3 superphyla (Archaeplastida, Fungi, and Protozoa) were positively correlated with the concentrations of spiked $\mathrm{Cu}$ (Pearson correlation, rho $>0.5$ and $p<0.05)$. Most of the Archaeplastida and 2 Stramenopiles species (Synurophyceae sp. and Goniochloris sculpta) declined consistently following the increase of spiked $\mathrm{Cu}$. One chlorophyte taxon (Chlorophyta sp.) was positively correlated with spiked $\mathrm{Cu}$.

Twenty-two out of 932 prokaryotic taxa from 4 phyla (Proteobacteria, Actinobacteria, Chloroflexi, and Cyanobacteria) were negatively correlated with increased concentrations of spiked $\mathrm{Cu}$ in both amphipod and chironomid experiments (Figure 4). Another 27 prokaryotic taxa positively correlated with increased concentrations of spiked $\mathrm{Cu}$ : approximately half of these taxa were from the Proteobacteria and Bacteroidetes phyla (Figure 4).

Difference between amphipod and chironomid tests

The compositions of prokaryotic communities in amphipod and chironomid experiments were similar. Most of the prokaryotic operational taxonomic units were shared by the 2 experiments at all $\mathrm{Cu}$ treatments (Figure 5A). The weighted UniFrac distance of prokaryotes between the 2 experiments had no significant change except at 
$125 \mathrm{mg} / \mathrm{kg}$ (Figure 5B). The shared eukaryotic operational taxonomic units between the 2 experiments decreased at high-Cu treatments (500 and $750 \mathrm{mg} / \mathrm{kg}$; Figure 5C). The weighted UniFrac distance of eukaryotes between the 2 experiments increased by $\mathrm{Cu}$ in a concentration-dependent manner (Figure 5D). Particularly, Ciliophora and Nematoda taxa had higher abundances in amphipod than in chironomid experiments, whereas Dinophyta and Archaeplastida had higher abundances in chironomid than in amphipod experiments (Figure 5E).

Thresholds of spiked Cu to microbiota in sediments

The relative abundance of 51 microbiota (22 prokaryotes and 29 eukaryotes) was decreased by spiked $\mathrm{Cu}$ in both amphipod and chironomid experiments. The threshold values of $\mathrm{Cu}$ in chironomid and amphipod experiments were 57.5 and $66 \mathrm{mg} / \mathrm{kg}$, respectively (Figure 6). This threshold means that at least $75 \%$ of sensitive microorganisms were affected by the spiked $\mathrm{Cu}$ in sediment.

\section{DISCUSSION}

The effects of spiked $\mathrm{Cu}$ on the composition of benthic microeukaryotic and prokaryotic communities in sediment were assessed by DNA metabarcoding in laboratory-based sediment toxicity tests with 2 different traditional test animals: amphipods and chironomids. Many microbiota taxa had similar responses to spiked $\mathrm{Cu}$ in both amphipod and chironomid tests. Furthermore, the trends of diversity decline in the eukaryotic community with increased concentrations of spiked $\mathrm{Cu}$ were similar in both 
tests. Because the microbiota have a significant ecological function on sediment processes, the indicators of community structure and biodiversity can be valuable for assessing the impacts of $\mathrm{Cu}$ contamination on aquatic systems.

Eukaryotic and prokaryotic communities showed distinct ecological responses to spiked $\mathrm{Cu}$. The relative abundance of most of the Archaeplastida and 2 Stramenopiles species (Synurophyceae sp. and Goniochloris sculpta) which carry out photosynthesis declined consistently following the increase of spiked $\mathrm{Cu}$. However, one chlorophyte taxon (Chlorophyta sp.) was positively correlated with the concentration of spiked $\mathrm{Cu}$, demonstrating a wide range of sensitivities among phototrophic species. This was consistent with previous mesocosm data showing that chlorophytes were both tolerant and sensitive to spiked-Cu treatments [7,33]. Nine fungal taxa (chytrid) $<\mathbf{Z A Q} \mathbf{Q} \mathbf{1}>$ were negatively associated with spiked $\mathrm{Cu}$, and 2 fungal taxa (Penicillium and Leotiomycetes) were positively associated with spiked $\mathrm{Cu}$. This was consistent with a previous long-term mesocosm study in which only the chytrid $<\mathbf{Z A Q}$;2 $>$ fungus was found to be sensitive to $\mathrm{Cu}$ [7], although fungal reproduction was reduced in high $\mathrm{Cu}$ concentrations [34]. In Fungi, various resistance mechanisms have been developed to overcome $\mathrm{Cu}$ toxicity, including $\mathrm{Cu}$ complexing by cell wall components, changes in membrane $\mathrm{Cu}$ transport, synthesis of intracellular $\mathrm{Cu}$-binding metallothioneins and phytochelatins, and production of extracellular $\mathrm{Cu}$ complexing [35,36]. This could explain why $\mathrm{Cu}$ failed to affect the relative abundance of most aquatic fungi [7]. 
None of the 15 nematode taxa was correlated with spiked $\mathrm{Cu}$, although nematodes have often been considered to be potential indicators for a range of environmental conditions [36-38]. In a previous long-term mesocosm study, most of the nematodes had no clear response to $\mathrm{Cu}$. Taken together, the presence and/or absence of nematode taxa may not be suitable to indicate long-term $\mathrm{Cu}$ contamination [7].

Most Protista taxa in the sediment microbial community were negatively correlated with spiked-Cu treatments. Protista are an important component of microbial communities and inhabit almost every habitat [39]. These taxa exhibit a range of sensitivities to metal toxicity, and the sensitivity of a single species varies from one toxicant to another [40]. To some extent, Protista have been suggested to be a useful tool for assessing pollution along with their role in controlling pollution through grazing of dispersed bacteria and maintenance of a healthy trophic web [41]. In the present study, a variety of Protista species were inhibited (relative abundance was reduced) by spiked-Cu treatments in a concentration-dependent manner; and therefore, these sensitive taxa may be good indicators of short-term $\mathrm{Cu}$ toxicity.

Some bacteria were negatively and other taxa were positively correlated with increased spiked-Cu concentrations. A substantial proportion of positively correlated bacteria were Bacteroidetes and Proteobacteria. Bacteria have evolved different mechanisms encoded by either chromosomal or plasmid genes to overcome $\mathrm{Cu}$ toxicity [35]. It is well known that the phylum Bacteroidetes comprises a high proportion of the total bacterial 
community in sediments [42]. The distribution of bacteria within this phylum has been correlated with algal blooms, plus many Bacteroidetes clones and isolates have been found in hydrocarbon-contaminated environments $[43,44]$. Nevertheless, the bacteria Actinobacteria, Chloroflexi, Cyanobacteria, and Proteobacteria were inhibited by $\mathrm{Cu}$ treatments in a concentration-dependent manner. Because Chloroflexi and Cyanobacteria are important autotrophic bacteria through photosynthesis, the decrease of Chloroflexi and Cyanobacteria indicated that the ability of photosynthesis by the bacterial community could be inhibited by $\mathrm{Cu}$ treatments. This result was consistent with $\mathrm{Cu}$ being used as an herbicide or to treat blue-green algal blooms.

The responses of microbiota communities to the spiked $\mathrm{Cu}$ were more sensitive than those of macroorganisms, which was consistent with previous studies $[7,8]$. But the Chao1 diversity index was not the most sensitive bioindex to the response of microbiota to contaminations. In addition, because of the high tolerance of bacteria, the Chao 1 index of prokaryotes failed to show a dose-dependent response to spiked $\mathrm{Cu}$. Principal component analysis showed that community structure measured by weighted UniFrac distance changed significantly if the concentration of spiked $\mathrm{Cu}$ was $>125 \mathrm{mg} / \mathrm{kg}$.

Although the main purpose of the present study was not to assess the effect of laboratory test animals on the composition of microbiota communities, some taxa showed different relative abundance between the sediments from the amphipod and the chironomid experiments. The different compositions between the 2 experiments may be 
caused by the bioturbation and feeding behavior of test animals. Bioturbation is a key process for the natural function of sediments, which influences cycling of nutrients as well as the physical characteristics of the sediment $[45,46]$. Previous studies demonstrated that bioturbation can result in significant structural and compositional changes in sediment bacterial communities, increasing bacterial diversity in surface sediments and resulting in distinct bacterial communities even at depth within the burrow $[45,47]$. The amphipod A. subtenuis establishes a burrow but does not frequently inhabit burrows or actively ventilate them. In contrast, the chironomid $C$. tepperi almost always occupies burrows. The different burrowing behaviors of the 2 macroinvertebrates could alter the availability of oxidants (oxygen, nitrate, ferric iron) in deeper sediment, which plays a key role in determining the presence and abundance of different microbial taxa [47]. The construction of burrows could also increase the sediment-water interface, offering additional surfaces for microbial colonization and chemical reactions; increase the transport of heavy metals into sediments [48,49]; and influence $\mathrm{Cu}$ bioavailability $[50,51]$.

Although the bioavailability of spiked $\mathrm{Cu}$ was not measured in the present study, the effects of experimental conditions (including test animals, feeding behavior, and frequency of water change) on the microbiota cannot be ignored. The weighted UniFrac distance of eukaryotes between amphipod and chironomid experiments increased in 
high-spiked $\mathrm{Cu}$ treatments, which further indicated that experimental animals could affect the response of microeukaryotes to spiked $\mathrm{Cu}$.

In the present study, a large number of eukaryotic and prokaryotic taxa across a broad range of groups in sediments were affected by the spiked $\mathrm{Cu}$. Eukaryotic diversity decreased and the composition of eukaryotic communities changed in the high-spiked $\mathrm{Cu}$ treatments. The calculated threshold values to the spiked $\mathrm{Cu}$ were consistent between the 2 experiments. The present study highlighted the value of the diversity and functional indicators using sediment microbial communities for monitoring and hazard assessment of sediment contamination.

Although the community responses of the microbiota to spiked $\mathrm{Cu}$ observed in the tank of the sediment toxicity test might not fully reflect what occurred in the field, the present data demonstrated that the microbiota is responsive to the stressor not only at the community level (i.e., Chao1 index) but also at the level of taxon (relative abundance). Some of these responses (indicators) were more sensitive than the responses of macroinvertebrates. The threshold of $\mathrm{Cu}$ in the present study indicated that the microbiota communities were altered by the spiked $\mathrm{Cu}$, but the results of the alterations were still unclear. Future studies are needed to translate these community responses at the genetic level into a functional level, which can be used to develop a next-generation approach for sediment quality assessment.

Acknowledgment-We thank the Environmental Protection Public Welfare Scientific 
Research Project of China (201409040) and Jiangsu Province Funds for Distinguished You 0000-0002-4006-8339ng Scientists (BK20130015). X. Zhang was supported by the Fundamental Research Funds for the Central Universities. The present study was also supported by the Collaborative Innovation Center for Regional Environmental Quality. We also thank Melbourne Water for funding the Centre for Aquatic Pollution Identification and Management's involvement in the study.

Data availability - The DNA sequences by next-generation sequencing were uploaded to the National Center for Biotechnology Information by Sequence Read Archive (SRR4241103).

References

1. Burton GA Jr. 1991. Assessing the toxicity of freshwater sediments. Environ Toxicol Chem 10:1585-1627.

2. Giesy JP, Hoke RA. 1991. Bioassessment of the toxicity of freshwater sediment. Verhandlungen des Internationalen Verein Limnologie 24:2313-2321.

3. Le Jeune AH, Charpin M, Deluchat V, Briand J-F. 2006. Effect of copper sulphate treatment on natural phytoplanktonic communities. Aquat Toxicol 80:267-280.

4. Shaw JL, Manning JP. 1996. Evaluating macroinvertebrate population and community level effects in outdoor microcosms: Use of in situ bioassays and multivariate analysis. Environ Toxicol Chem 15:608-617. 
5. Roussel H, Ten-Hage L, Joachim S, Le Cohu R, Gauthier L, Bonzom J-M. 2007. A long-term copper exposure on freshwater ecosystem using lotic mesocosms: Primary producer community responses. Aquat Toxicol 81:168-182.

6. Wang F, Goulet RR, Chapman PM. 2004. Testing sediment biological effects with the freshwater amphipod Hyalella azteca: The gap between laboratory and nature.

Chemosphere 57:1713-1724.

7. Gardham S, Hose GC, Stephenson S, Chariton AA. 2014. DNA metabarcoding meets experimental ecotoxicology: Advancing knowledge on the ecological effects of copper in freshwater ecosystems. In Woodward G, Dumbrell AJ, Baird DJ, Hajibabaei M, eds, Big Data in Ecology. Vol 51—Advances in Ecological Research. Academic, London, UK, pp 79-104.

8. Mayor DJ, Gray NB, Elver-Evans J, Midwood AJ, Thornton B. 2013.

Metal-macrofauna interactions determine microbial community structure and function in copper contaminated sediments. PLoS One 8:e64940.

9. Gadd GM, Raven JA. 2010. Geomicrobiology of eukaryotic microorganisms. Geomicrobiology Journal 27:491-519.

10. Lozupone CA, Knight R. 2007. Global patterns in bacterial diversity. P Natl Acad Sci USA 104:11436-11440. 
11. Heijden MGAVD, Bardgett RD, Straalen NMV. 2008. The unseen majority: Soil microbes as drivers of plant diversity and productivity in terrestrial ecosystems. Ecol Lett $11: 296-310$.

12. Wagg C, Bender SF, Widmer F, Mg VDH. 2014. Soil biodiversity and soil community composition determine ecosystem multifunctionality. P Natl Acad Sci USA

111:5266-5270.

13. Elsas JDV, Salles JF. 2012. Microbial diversity determines the invasion of soil by a bacterial pathogen. P Natl Acad Sci USA 109:1159-1164.

14. Philippot L, Spor A, Hénault C, Bru D, Bizouard F, Jones CM, Sarr A, Maron PA. 2013. Loss in microbial diversity affects nitrogen cycling in soil. ISME J 7:1609-1619.

15. Chariton AA, Court LN, Hartley DM, Colloff MJ, Hardy CM. 2010. Ecological assessment of estuarine sediments by pyrosequencing eukaryotic ribosomal DNA. Front Ecol Environ 8:233-238.

16. Chariton AA, Ho KT, Proestou D, Bik H, Simpson SL, Portis LM, Cantwell MG, Baguley JG, Burgess RM, Pelletier MM, Perron M, Gunsch C, Matthews RA. 2014. A molecular-based approach for examining responses of eukaryotes in microcosms to contaminant-spiked estuarine sediments. Environ Toxicol Chem 33:359-369.

17. Bohmann K, Evans A, Gilbert MTP, Carvalho GR, Creer S, Knapp M, Yu DW, Bruyn MD. 2014. Environmental DNA for wildlife biology and biodiversity monitoring. Trends Ecol Evol 29:358-367. 
18. Simpson SL, Batley GE, Charlton AA, Stauber JL, King CK, Chapman JC, Hyne RV, Gale SA, Roach AC, Maher WA. 2005. Handbook for Sediment Quality Assessment. CSIRO, Bangor, NSW, Australia.

19. Hutchins CM, Teasdale PR, Lee SY, Simpson SL. 2008. Cu and Zn concentration gradients created by dilution of $\mathrm{pH}$ neutral metal-spiked marine sediment: A comparison of sediment geochemistry with direct methods of metal addition. Environ Sci Technol 42:2912-2918.

20. Jeppe KJ, Yang J, Long SM, Carew ME, Zhang X, Pettigrove V, Hoffmann AA. 2017. Detecting copper toxicity in sediments: From the subindividual level to the population level. J Appl Ecol 54:1331-1342.

21. Gagliardi BS, Long SM, Pettigrove VJ, Hoffmann AA. 2015. The parthenogenetic cosmopolitan chironomid, Paratanytarsus grimmii, as a new standard test species for ecotoxicology: Culturing methodology and sensitivity to aqueous pollutants. B Environ Contam Tox 95:350-356.

22. Vu HT, Keough MJ, Long SM, Pettigrove VJ. 2017. Effects of two commonly used fungicides on the amphipod Austrochiltonia subtenuis. Environ Toxicol Chem $36: 720-726$.

23. Klindworth A, Pruesse E, Schweer T, Peplies J, Quast C, Horn M, Gloeckner FO. 2013. Evaluation of general 16S ribosomal RNA gene PCR primers for classical and 
next-generation sequencing-based diversity studies. Nucleic Acids Res 41:e1. DOI:

10.1093/nar/gks808.

24. Amaral-Zettler LA, McCliment EA, Ducklow HW, Huse SM. 2009. A method for studying protistan diversity using massively parallel sequencing of V9 hypervariable regions of small-subunit ribosomal RNA genes. PLoS One 4:e6372.

25. Caporaso JG, Kuczynski J, Stombaugh J, Bittinger K, Bushman FD, Costello EK, Fierer N, Pena AG, Goodrich JK, Gordon JI, Huttley GA, Kelley ST, Knights D, Koenig JE, Ley RE, Lozupone CA, McDonald D, Muegge BD, Pirrung M, Reeder J, Sevinsky JR, Tumbaugh PJ, Walters WA, Widmann J, Yatsunenko T, Zaneveld J, Knight R. 2010. QIIME allows analysis of high-throughput community sequencing data. Nature Methods $7: 335-336$.

26. Edgar RC. 2013. UPARSE: Highly accurate OTU sequences from microbial amplicon reads. Nature Methods 10:996-998.

27. Wang Q, Garrity GM, Tiedje JM, Cole JR. 2007. Naive Bayesian classifier for rapid assignment of rRNA sequences into the new bacterial taxonomy. Appl Environ Microb 73:5261-5267.

28. Desantis TZ, Hugenholtz P, Larsen N, Rojas M, Brodie EL, Keller K, Huber T, Dalevi D, Hu P, Andersen GL. 2006. Greengenes, a chimera-checked 16S rRNA gene database and workbench compatible with ARB. Appl Environ Microb 72:5069-5072. 
29. Pruesse E, Quast C, Knittel K, Fuchs BM, Ludwig W, Peplies J, Gloeckner FO. 2007. SILVA: A comprehensive online resource for quality checked and aligned ribosomal RNA sequence data compatible with ARB. Nucleic Acids Res 35:7188-7196.

30. Ritz C, Baty F, Streibig JC, Gerhard D. 2015. Dose-response analysis using R. PLoS One 10:e0146021.

31. Lozupone C, Knight R. 2006. UniFrac: A new phylogenetic method for comparing microbial communities. Appl Environ Microb 71:8228-8235.

32. Tuomisto H. 2010. A diversity of beta diversities: Straightening up a concept gone awry. Part 2. Quantifying beta diversity and related phenomena. Ecography 33:23-45. 33. Knauer K, Behra R, Sigg L. 1997. Effects of free $\mathrm{Cu}^{2+}$ and $\mathrm{Zn}^{2+}$ ions on growth and metal accumulation in freshwater algae. Environ Toxicol Chem 16:220-229.

34. Duarte S, Pascoal C, Cassio F. 2009. Functional stability of stream-dwelling microbial decomposers exposed to copper and zinc stress. Freshwater Biol 54:1683-1691.

35. Cervantes C, Gutierrezcorona F. 1994. Copper resistance mechanisms in bacteria and fungi. FEMS Microbiol Rev 14:121-137.

36. Ding C, Festa RA, Chen Y-L, Espart A, Palacios O, Espin J, Capdevila M, Atrian S, Heitman J, Thiele DJ. 2013. Cryptococcus neoformans copper detoxification machinery is critical for fungal virulence. Cell Host Microbe 13:265-276. 
37. Boyd WA, Williams PL. 2003. Comparison of the sensitivity of three nematode species to copper and their utility in aquatic and soil toxicity tests. Environ Toxicol Chem 22:2768-2774.

38. Bongers T, Ferris H. 1999. Nematode community structure as a bioindicator in environmental monitoring. Trends Ecol Evol 14:224-228.

39. Novarino G, Warren A, Butler H, Lambourne G, Boxshall A, Bateman J, Kinner NE, Harvey RW, Mosse RA, Teltsch B. 1997. Protistan communities in aquifers: A review. FEMS Microbiol Rev 20:261-275.

40. Madoni P, Davoli D, Gorbi G, Vescovi L. 1996. Toxic effect of heavy metals on the activated sludge protozoan community. Water Res 30:135-141.

41. Nicolau A, Martins MJ, Mota M, Lima N. 2005. Effect of copper in the protistan community of activated sludge. Chemosphere 58:605-614.

42. Kim BS, Oh HM, Kang H, Park SS, Chun J. 2004. Remarkable bacterial diversity in the tidal flat sediment as revealed by $16 \mathrm{~S}$ rDNA analysis. J Microbiol Biotechnol $14: 205-211$.

43. Kim SJ, Kwon KK. 2010. Bacteroidetes. In Timmis KN, ed, Handbook of Hydrocarbon \& Lipid Microbiology. Springer, Heidelberg, Germany, pp 1814-1817.

44. Bauer M, Kube M, Teeling H, Richter M, Lombardot T, Allers E, Würdemann CA, Quast C, Kuhl H, Knaust F. 2006. Whole genome analysis of the marine Bacteroidetes 
"Gramella forsetii" reveals adaptations to degradation of polymeric organic matter. Environ Microbiol 8:2201-2213.

45. Laverock B, Smith CJ, Tait K, Osborn AM, Widdicombe S, Gilbert JA. 2010.

Bioturbating shrimp alter the structure and diversity of bacterial communities in coastal marine sediments. ISME J 4:1531-1544.

46. Gilbertson WW, Solan M, Prosser JI. 2012. Differential effects of microorganism-invertebrate interactions on benthic nitrogen cycling. FEMS Microbiol Ecol 82:11-22.

47. Bertics VJ, Ziebis W. 2009. Biodiversity of benthic microbial communities in bioturbated coastal sediments is controlled by geochemical microniches. ISME J 3:1269-1285.

48. Marinelli RL, Lovell CR, Wakeham SG, Ringelberg DB, White DC. 2002. Experimental investigation of the control of bacterial community composition in macrofaunal burrows. Mar Ecol-Prog Ser 235:1-13.

49. Grossmann S, Reichardt W. 1991. Impact of Arenicola marina on bacteria in intertidal sediments. Mar Ecol-Prog Ser 77:85-93.

50. Bat L, Raffaelli D, Marr IL. 1998. The accumulation of copper, zinc and cadmium by the amphipod Corophium volutator (Pallas). J Exp Mar Biol Ecol 223:167-184.

51. Icely JD, Nott JA. 1980. Accumulation of copper within the "hepatopancreatic" caeca of Corophium volutator (Crustacea: Amphipoda). Mar Biol 57:193-199. 
Figure 1. Dry weight, survival rate, and emergence of Chironomus tepperi (chironomid) in spiked-Cu sediment. (A) Effect of spiked $\mathrm{Cu}$ on the survival rate, dry weight, and emergence rate of chironomids. Blue solid line $=$ emergence rate, blue dotted line $=$ survival rate, and red solid line = emergence rate. (B) Effect of spiked Cu on emergence during the exposure period. (C) Effect of spiked $\mathrm{Cu}$ on the survival of Austrochiltonia subtenuis (amphipod). EC50 = median effect concentration; $\mathrm{ET}=$ emergence time.

Figure 2. Composition of microbial communities in sediments from ecotoxicity test using amphipods or chironomids.

Figure 3. Structures and diversity of eukaryotic and prokaryotic communities in spiked-Cu sediments. (A) Principal component analysis of prokaryotic community components in amphipod and chironomid experiments. (B) Principal component analysis of eukaryotic community components in amphipod and chironomid experiments. (C) Effects of spiked $\mathrm{Cu}$ on the Chao1 diversity of eukaryotic and prokaryotic communities in chironomid experiments. (D) Effects of spiked $\mathrm{Cu}$ on the Chao1 diversity of eukaryotic and prokaryotic communities in amphipod experiments. Significance was determined with one-way analysis of variance and Tukey's post hoc tests $\left({ }^{*} p<0.05,{ }^{* *} p<0.01\right)$. PC $=$ principal component.

Figure 4. Eukaryotic and prokaryotic taxa affected by spiked $\mathrm{Cu}$ in both amphipod and chironomid sediment toxicity test experiments. The "affected taxa" were screened by the Pearson correlation analysis $(p<0.05$ and rho $>0.5)$. The color indicates the fold change of the abundance of each taxon: orange $=$ abundance is up; green $=$ abundance is down . Figure 5. Differences in microbiota between amphipod and chironomid experiments. (A) Prokaryotic and (B) eukaryotic composition between amphipod and chironomid tests. 
"Shared OTUs" means the operational taxonomic units were detected in both experiments. "Amphipod only" and "Chironomid only" mean the operational taxonomic units were only detected in amphipod and chironomid tests, respectively. (C) Weighted UniFrac distance of prokaryotes and (D) eukaryotes between amphipod and chironomid tests. (E) Four eukaryotic taxa have different abundance between amphipod and chironomid experiments. Dots represent the relative abundance of taxa, and error bars are the standard deviations. Significance was determined with 2-sample $t$ tests $\left({ }^{*} p<0.05,{ }^{* *} p\right.$ $<0.01, \stackrel{* * *}{p} p<0.001)$

Figure 6. Responses of sensitive microbiota to the spiked $\mathrm{Cu}$ in sediment. (A)

Chironomid experiment. (B) Amphipod experiment. The abundance of each sensitive taxon was normalized by the formula $\frac{\boldsymbol{x}-\min (x)}{\max (x)-\min (x)}$, where $x$ is the abundance of each taxon. The relationship between normalized abundance (unaffected proportion) and spiked $\mathrm{Cu}$ was fitted by the 3-parameter log-logistic model, and then the $10 \%$ effect concentration (EC10) was calculated. The threshold of $\mathrm{Cu}$ was determined by the lower quartiles of the EC10 values of all sensitive taxa.

$<<$ ENOTE $>>$ AQ1: Should "chytrid" be Chytridiomycetes or Chytridiomycota? $<<$ ENOTE $>>$ AQ2: Should "chytrid" be Chytridiomycetes or Chytridiomycota? $<<$ ENOTE $>$ AQ3: Bold font is not used by ET\&C to differentiate things within tables, instead different letters are used to denote significant difference, please check that the different factions are labeled correctly using A and B. 
Table 1. Analysis of variance Dunnett's test on weighted UniFrac distances of prokaryotic and eukaryotic communities between spiked-Cu treatments: Mean \pm standard deviation

\begin{tabular}{|c|c|c|c|c|}
\hline \multirow[b]{2}{*}{ Spiked-Cu } & \multicolumn{2}{|c|}{ Chironomid $^{\mathrm{a}}<\mathbf{Z A Q}$;3> } & \multicolumn{2}{|c|}{ Amphipod $^{\mathrm{a}}$} \\
\hline & Prokaryotic & Eukaryotic & Prokaryotic & Eukaryotic \\
\hline$(\mathrm{mg} / \mathrm{kg})$ & community & community & community & community \\
\hline 0 & $0.40 \pm 0.01$ & $0.22 \pm 0.05$ & $0.40 \pm 0.00$ & $0.18 \pm 0.06$ \\
\hline 62.5 & $0.41 \pm 0.02$ & $0.23 \pm 0.04$ & - & - \\
\hline 125 & $0.42 \pm 0.02$ & $0.23 \pm 0.06$ & $0.43 \pm 0.01 \mathrm{~A}^{* *}$ & $0.35 \pm 0.04 \mathrm{~A}^{* *}$ \\
\hline 250 & $0.45 \pm 0.02 \mathrm{~B}^{*}$ & $0.31 \pm 0.07$ & $0.47 \pm 0.01 \mathrm{~A}^{* *}$ & $0.36 \pm 0.03 \mathrm{~A}^{* *}$ \\
\hline 500 & $0.47 \pm 0.02 \mathrm{~A}^{* *}$ & $0.37 \pm 0.05 \mathrm{~B}^{*}$ & $0.51 \pm 0.02 \mathrm{~A}^{* *}$ & $0.44 \pm 0.05 \mathrm{~A}^{* *}$ \\
\hline 750 & $0.49 \pm 0.02 \mathrm{~A}^{* *}$ & $0.55 \pm 0.10 \mathrm{~A}^{* *}$ & $0.52 \pm 0.02 \mathrm{~A}^{* *}$ & $0.55 \pm 0.01 \mathrm{~A}^{* * *}$ \\
\hline
\end{tabular}

${ }^{a}$ Different letters denote significant difference among treatments.

$* p<0.01, * * p<0.001$. 
Fig.1
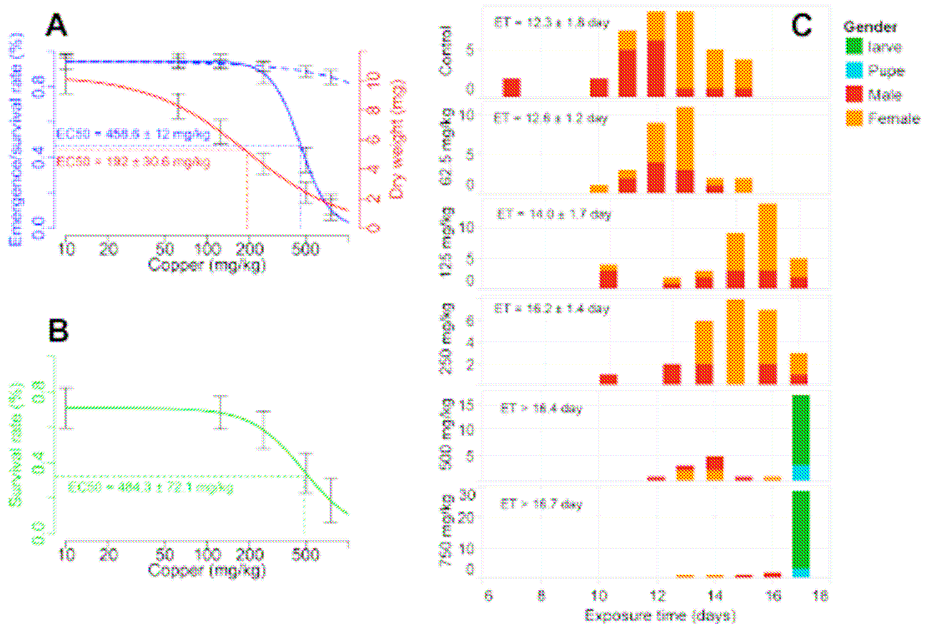

Fig. 2

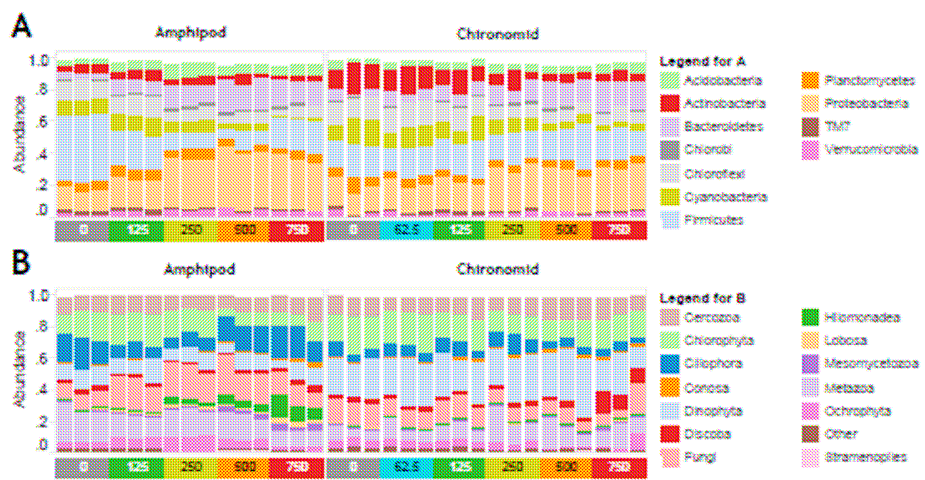


Fig 3

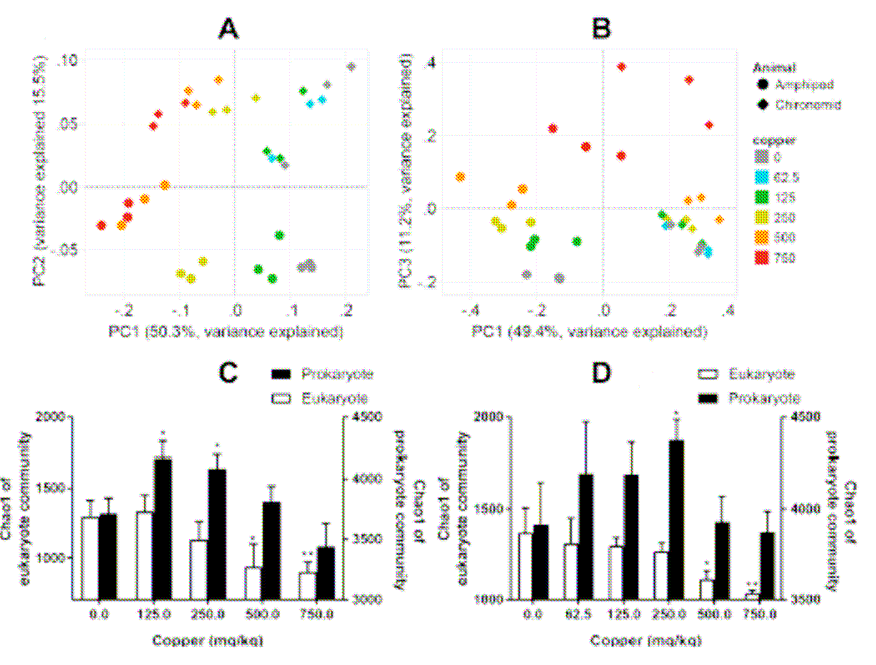




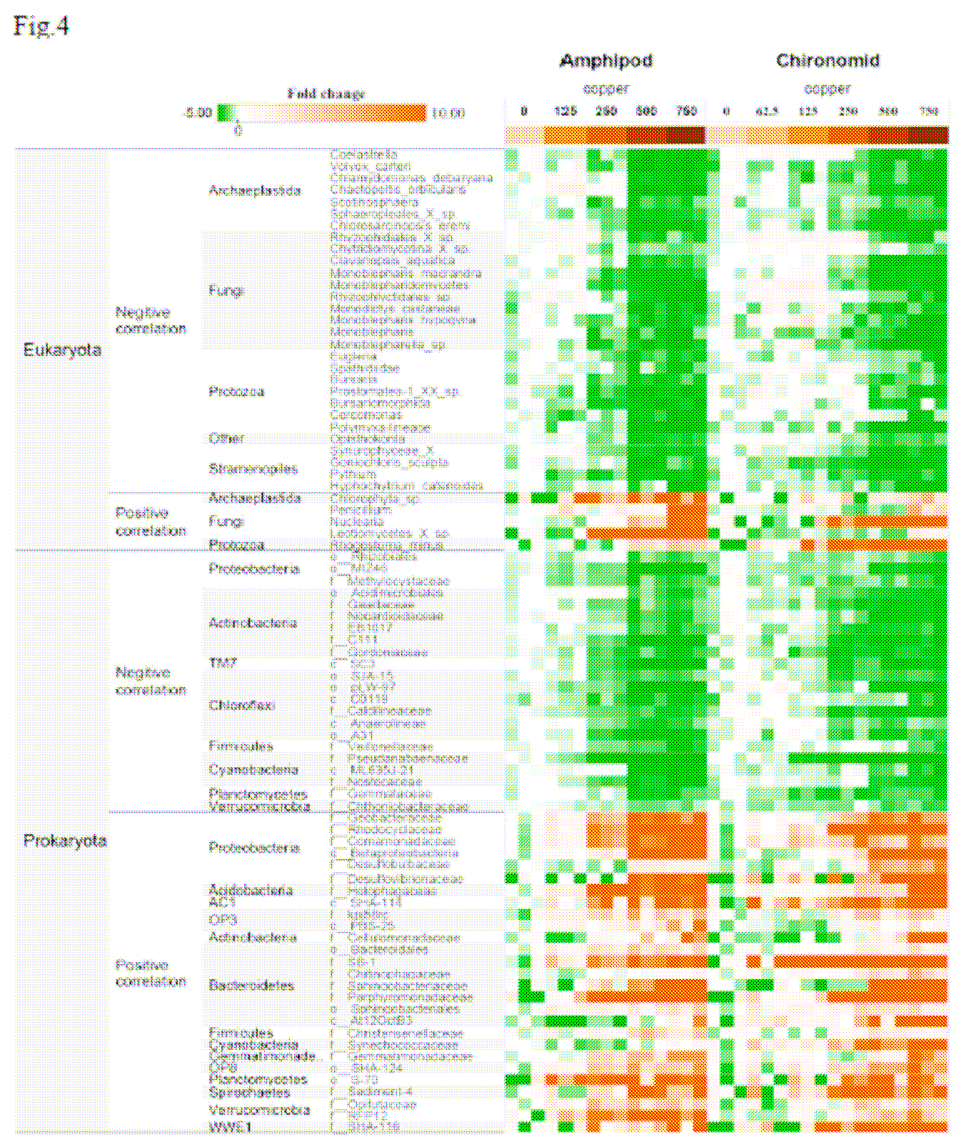



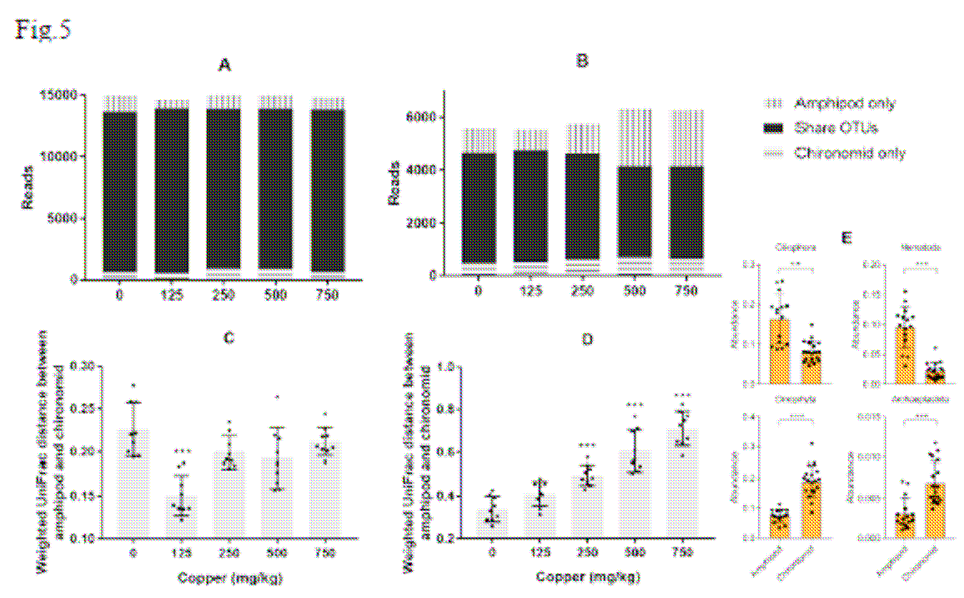

Fig. 6

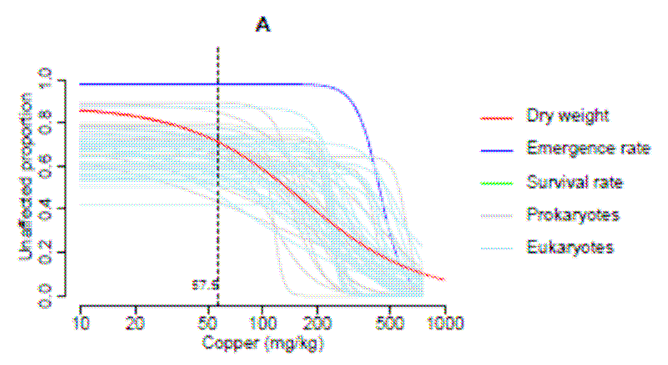

B

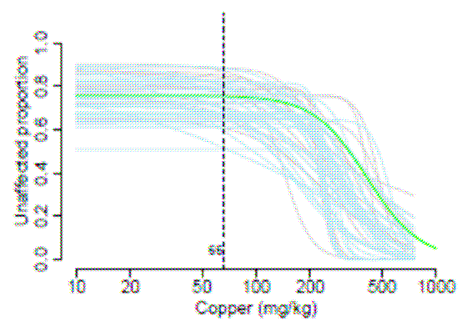

Table 1. Analysis of variance Dunnett's test on weighted UniFrac distances of prokaryotic and eukaryotic communities between spiked-Cu treatments: Mean \pm standard deviation 


\begin{tabular}{|c|c|c|c|c|}
\hline \multirow{3}{*}{$\begin{array}{l}\text { Spiked-Cu } \\
(\mathrm{mg} / \mathrm{kg})\end{array}$} & \multicolumn{2}{|c|}{ Chironomid $^{\mathrm{a}}<\mathbf{Z A Q} ; 3>$} & \multicolumn{2}{|c|}{ Amphipod $^{\mathrm{a}}$} \\
\hline & Prokaryotic & Eukaryotic & Prokaryotic & Eukaryotic \\
\hline & community & community & community & community \\
\hline 0 & $0.40 \pm 0.01$ & $0.22 \pm 0.05$ & $0.40 \pm 0.00$ & $0.18 \pm 0.06$ \\
\hline 62.5 & $0.41 \pm 0.02$ & $0.23 \pm 0.04$ & - & - \\
\hline 125 & $0.42 \pm 0.02$ & $0.23 \pm 0.06$ & $0.43 \pm 0.01 \mathrm{~A}^{* *}$ & $0.35 \pm 0.04 \mathrm{~A}^{* *}$ \\
\hline 250 & $0.45 \pm 0.02 \mathrm{~B}^{*}$ & $0.31 \pm 0.07$ & $0.47 \pm 0.01 \mathrm{~A}^{* *}$ & $0.36 \pm 0.03 \mathrm{~A}^{* *}$ \\
\hline 500 & $0.47 \pm 0.02 \mathrm{~A}^{* *}$ & $0.37 \pm 0.05 \mathrm{~B}^{*}$ & $0.51 \pm 0.02 \mathrm{~A}^{* *}$ & $0.44 \pm 0.05 \mathrm{~A}^{* *}$ \\
\hline 750 & $0.49 \pm 0.02 \mathrm{~A}^{* *}$ & $0.55 \pm 0.10 A^{* *}$ & $0.52 \pm 0.02 \mathrm{~A}^{* *}$ & $0.55 \pm 0.01 \mathrm{~A} * *$ \\
\hline
\end{tabular}

${ }^{a}$ Different letters denote significant difference among treatments.

${ }^{*} p<0.01, * * p<0.001$. 


\section{University Library}

\section{- M M N E R VA A gateway to Melbourne's research publications}

Minerva Access is the Institutional Repository of The University of Melbourne

Author/s:

Yang, J;Xie, Y;Jeppe, K;Long, S;Pettigrove, V;Zhang, X

Title:

Sensitive Community Responses of Microbiota to Copper in Sediment Toxicity Test

Date:

2018-02-01

Citation:

Yang, J., Xie, Y., Jeppe, K., Long, S., Pettigrove, V. \& Zhang, X. (2018). Sensitive Community Responses of Microbiota to Copper in Sediment Toxicity Test. ENVIRONMENTAL

TOXICOLOGY AND CHEMISTRY, 37 (2), pp.599-608. https://doi.org/10.1002/etc.3980.

Persistent Link:

http://hdl.handle.net/11343/293940 